\title{
Hair Anomalies in a 6-Year-0ld Girl
}

\author{
M. Wruhs, C. Bergthaler, F. Breier, A. Steiner, P. Sator \\ Department of Dermatology, KH Hietzing, Vienna, Austria \\ Email: marlies.wruhs@wienkav.at, carina.bergthaler@wienkav.at, friedrich.breier@wienkav.at, \\ andreas.steiner@wienkav.at, paul.sator@wienkav.at
}

Received 11 January 2016; accepted 7 March 2016; published 10 March 2016

Copyright (C) 2016 by authors and Scientific Research Publishing Inc.

This work is licensed under the Creative Commons Attribution International License (CC BY).

http://creativecommons.org/licenses/by/4.0/

(c) (i) Open Access

\begin{abstract}
Monilehtrix is a rare inherited hair shaft disorder with considerable variations in age of onset severity and course. We present a 6-year-old girl with monilethrix and discuss different aspects of the disease and its treatment.
\end{abstract}

Keywords

Monilethrix, Hair Shaft Disorder

\section{Introduction}

Monilethrix or beading of hair is a mostly autosomal dominant inherited hair shaft disorder with high penetrance but variable expressivity [1]. It usually starts in the first few month of life and then persists throughout life. It is characterized by short and fragile hair [2].

\section{Case Report}

A 6 year-old girl presented with increasing alopecia (Figure 1). According to her parents hair has never been longer than $2 \mathrm{~cm}$. They also report a wide variety of hair problems within the family over the last 4 generations (Figure 2).

The child is in good shape. Hair over the scalp is short, fragile and brittle. Number of hair is reduced. Occipital follicular keratosis is found. Hair is about $1.5 \mathrm{~cm}$ long, only parietal there are scattered hairs with maximal 2 $\mathrm{cm}$ length. The entire dermatological status, including nails is unremarkable.

Light microscopy showed beaded appearance of hair with nodes separated by internodes (Figure 3).

Thus establishing the diagnosis of monilethrix.

No treatment was started, but the patient was advised to avoid any trauma of the hair. 


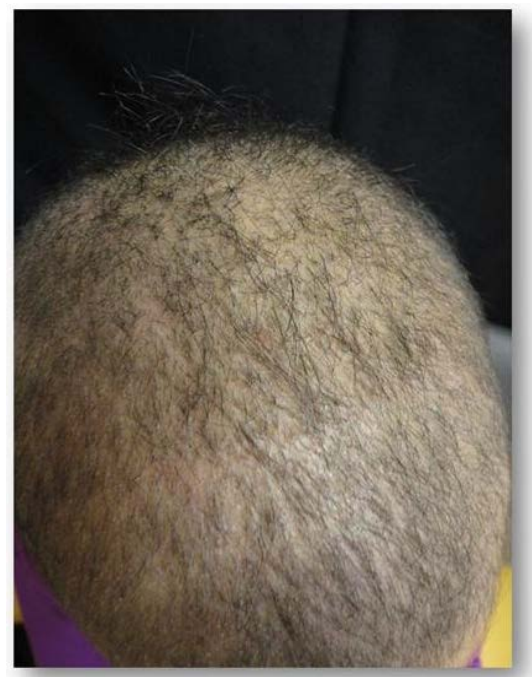

Figure 1. Clinical findings.

Affected woman

Not affected woman

Affected man

Not affected man

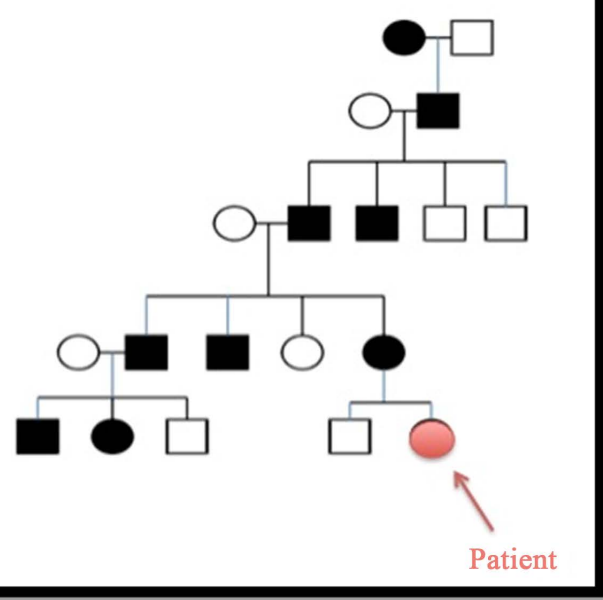

Figure 2. Pedigree chart.

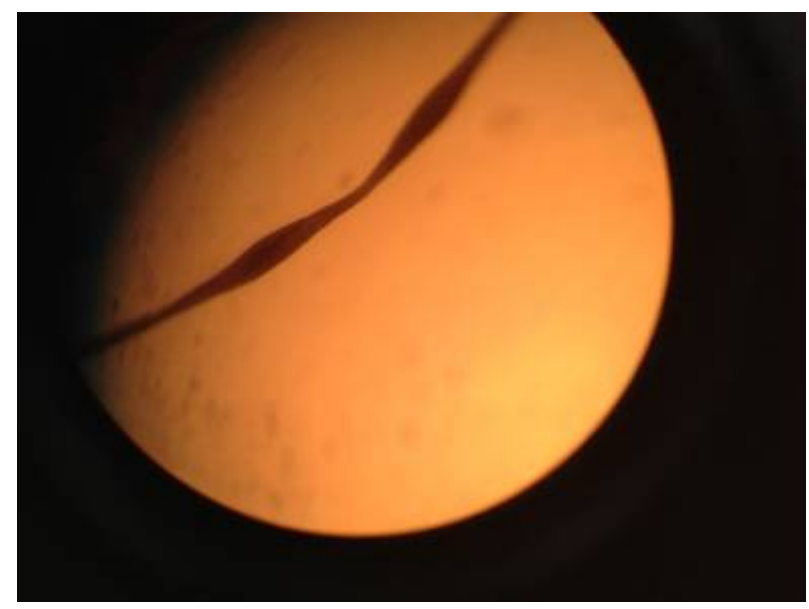

Figure 3. Light microscopy of the hair. 


\section{Discussion}

Monilethrix is a mostly autosomal dominant inherited hair shaft disorder caused by mutations in the hHB1, hHB3 and hHB6 keratin gene on chromosome 12q11-q13. In the autosomal recessive type, different mutations in desmoglein 4 were found. Because of different allelic variants clinical presentation can be very variable. It shows considerable variations in age of onset severity and course. Hair is usually normal at birth and is progressively replaced by abnormal hair during first few month of life [2]. Ranging from clinically almost unimaginable to complete baldness, in serve cases the hole body hair can be affected. Clinical findings can include nail changes and keratosis pilaris of the skin of neck and arms [3]. In literature, case reports with the simultaneous presence of cataract or mental retardation are described. Hair microscopy shows elliptical nodes of normal thickness separated by abnormal constrictions resulting from defective cortical cell keratinization [4].

Congenitally abnormal hair tends to have an increased susceptibility to weathering and cosmetic damage, which can prevent hair from growing to its maximal length. There is still no definitive treatment recognized [5]. Avoiding traumata is the most effective method of managing this anomaly. Hormonal influence may improve the hair disorder. In some females hair growths increased after first menstrual period [6]. Treatment trials of systemically administered retinoids [7], N-acetylcysteine [8], 2\% minoxidil [9] locally have taken place, however, shown only moderate success.

\section{References}

[1] Glaser, B., Horev, L. and Zlotogorski, A. (1998) Monilethrix: A Keratin hHb6 Mutation Is Co-Dominant with Variable Expression. Experimental Dermatology, 7, 268-272.

[2] Sathyanaryana, B.D. (1998) Case Report-Monilethrix. Indian Journal of Dermatology, Venereology and Leprology, 64, 5.

[3] von Steensel, M.A.M., Steijlen, P.M., Bladergroen, R.S., et al. (2005) A Missense Mutation in the Type II Hair Keratin hHb3 Is Associated with Monilethrix. Journal of Medical Genetics, 42, e19. http://dx.doi.org/10.1136/jmg.2004.021030

[4] Bindurani, S. and Rajiv, S. (2013) Monilethrix with Variable Expressivity. International Journal of Tricology, 5, 53-55. http://dx.doi.org/10.4103/0974-7753.114703

[5] Narmatha, G.R., Chithra, S. and Balasubramanian, N. (2002) Monilethrix. Indian Journal of Dermatology, Venereology and Leprology, 68, 220-221.

[6] Gebhardt, M., Fischer, T., Claussen, U., et al. (1999) Monilethrix-Improvement by Hormonal Influences? Pediatric Dermatology, 16, 297-300. http://dx.doi.org/10.1046/j.1525-1470.1999.00078.x

[7] Karincaoglu, Y., Coskun, B.K., Seyhan, M.E., et al. (2005) Monilethrix: Improvement Wirhacitretin. American Journal of Clinical Dermatology, 6, 407-410. http://dx.doi.org/10.2165/00128071-200506060-00008

[8] Vikramkumar, A.G., Kuruvila, S. and Ganguly, S. (2013) Monilethrix: A Rare Hereditary Condition. Indian Journal of Dermatology, 58, 243. http://dx.doi.org/10.4103/0019-5154.110869

[9] Rossi, A., Iorio, A., Scali, E., et al. (2011) Monilethrix Treated with Minoxidil. International Journal of Immunopathology and Pharmacology, 24, 239-242. 